\title{
Kualitas Pelayanan Frontliner dan Kepuasan Nasabah
}

\author{
Oleh: \\ Dewi Reni \\ Siri Asmawati
}

Sekolah Tinggi Ekonomi Syariah (STES) Islamic Village
Jln Raya Islamic Kelapa Dua Tangerang 15810, Indonesia

\begin{abstract}
Abstrak: Penelitian ini bertujuan untuk menguji pengaruh kualitas pelayanan frontliner dengan kepuasan nasabah pada PT. Bank Syariah Mandiri Cabang Cikupa dan seberapa signifikan keadaan pengaruh tersebut. Penelitian ini menggunakan metode kuesioner/angket dan observasi. Kuesioner/angket digunakan untuk memperoleh data tentang karakteristik responden yaitu nasabah dan untuk memperoleh data tentang pengaruh kualitas pelayanan frontliner dengan kepuasan nasabah pada PT. Bank Syariah Mandiri Cabang Cikupa melalui pernyataan/pertanyaan dalam kuesioner/angket tersebut. Sedangkan observasi digunakan untuk pengamatan langsung tempat penelitian serta mengali data tentang strukstur organisasi, populasi dan sampel. Hasil penelitian menunjukkan bahwa persepsi responden terhadap kualitas pelayanan frontliner dalam kategori cukup baik dan terhadap kepuasan nasabah dalam kategori cukup puas.

Kata kunci: kualitas, pelayanan, frontliner, dan kepuasan nasabah
\end{abstract}

\section{Pendahuluan}

Dalam dunia perekonomian banyak usaha baik di sektor riil maupun di sektor financial yang ikut andil dalam meningkatkan taraf kehidupan banyak orang. Salah satu pelaku usaha yang ikut mengembangkan perekonomian negeri ini yaitu Bank. Bank merupakan badan usaha yang menghimpun dana dari masyarakat dalam bentuk simpanan dan menyalurkannya kepada masyarakat dalam bentuk kredit dan atau bentuk lainnya dalam rangka meningkatkan taraf hidup orang banyak.

Dalam dunia perbankan dikenal pula bank umum, bank umum menurut UU RI No. 10 Tahun 1998 adalah bank yang melaksanakan kegiatan usaha secara konvensional dan atau berdasarkan Prinsip Syariah yang dalam kegiatannya memberikan jasa dalam lalu lintas pembayaran. Bank umum dibedakan menjadi dua yaitu bank umum konvensional dan bank umum syariah. 
Awal kemunculan bank syariah di Indonesia didahului oleh berdirinya Bank Muamalat Indonesia pada tahun 1992. Salah satu alasannya yaitu kebutuhanmasyarakat muslim akan jasa keuangan yang tidak berprinsip bunga sebagaimana diterapkan oleh bank konvensional. Selain itu, bank syariah juga menunjukkan keberadaannya dengan tetap berdiri walaupun gelombang krisis moneter menerpa perekonomian Indonesia pada tahun 1999. Sementara itu, bank konvensional mengalami pailit bahkan ada yang harus dimerger dengan bank lainnya. Bank konvensional sangat rentan terhadap perubahan ekonomi misalnya karena inflasi, karena sistem yang digunakannya yaitu sistem bunga. Berbanding terbalik dengan bank syariah, sistem yang membawanya tetap berdiri tanpa goyah yaitu prinsip bagi hasil, yang tidak terpengaruh oleh perubahan suku bunga maupun inflasi. Oleh karena itu mulai bermunculan bank-bank yang menerapkan sistem bagi hasil atau prinsip syariah di Indonesia (Hasan, 2010: 95).

Bank syariah secara yuridis normatif dan yuridis empiris diakui keberadaannya di negara Republik Indonesia. Pengakuan secara yuridis normatif sebagaimana peraturan perundang-undangan di Indonesia, diantaranya Undang-undang No. 7 Tahun 1992 tentang Perbankan, Undangundang No. 10 Tahun 1998 tentang Perubahan atas Undang- undang No. 7 Tahun 1992 tentang Perbankan, Undang-undang No. 3 Tahun 2004 tentang Perubahan atas Undang-undang No. 23 Tahun 1999 tentang Bank Indonesia, Undang-undang No. 3 Tahun 1989 tentang Peradilan Agama dan Undangundang No. 21 Tahun 2008 tentang perbankan syariah. Selain itu, pengakuan secara yuridis empiris dapat diketahui perbankan syariah tumbuh dan berkembang pada umumnya di seluruh ibukota provinsi dan kabupaten di Indonesia, bahkan beberapa bank konvensional dan lembaga keuangan lainnya membuka unit usaha syariah (bank syariah, asuransi syariah, pegadaian syariah dan semacamnya). Pengakuan secara yuridis dimaksud memberi kesempatan kepada bank umum (konvensional) untuk membuka kantor cabang yang khusus melakukan kegiatan usaha berdasarkan prinsip syariah. (Susilowati, 2013:01)

Perubahan lingkungan perusahaan dan semakin tingginya tuntutan dari nasabah memaksa pihak manajemen untuk selalu melakukan inovasi guna mempertahankan nasabah-nasabahnya, sehingga dapat menjadi nasabah yang loyal terhadap bank.Salah satu tindakan untuk memuaskan nasabah dengan cara memberikan pelayanan kepada nasabah dengan sebaik-baiknya. Kenyataan ini bisa dilihat, bahwa ada beberapa hal yang dapat memberikan kepuasan nasabah yaitu total pelanggan yang terdiri dari nilai produk, nilai pelayanan, nilai personal, nilai image (citra), dan biaya moneter, biaya waktu, biaya tenaga dan biaya pikiran (Kotler dkk, 2000:50).

Suatu hal nyata terjadi pada perusahaan perbankan di Indonesia, di mana setiap nasabah akan menginginkan pelayanan yang sesuai dengan 
harapan. Perlakuan seorang teller yang buruk terhadap nasabah disaat melakukan transaksi jasa keuangan pada bank tertentu akan membuat image bank tersebut turun di mata masyarakat sebagai effect pernyataan secara tertulis keluhan atau ketidakpuasan pelayanan dari seorang pegawai teller bank tertentu kepada seorang nasabahnya yang disebarkan ke media massa (Yuli 2012:84)

Mengingat pentingnya menjaga kualitas pelayanan bank terhadap nasabahnya dalam rangka menjawab tantangan dalam persaingan dewasa ini maka bank harus selalu mampu mengukur sejauh mana kualitas dan juga tingkat kepuasan nasabah atas hasil dari pelayanan yang mereka berikan. Dalam pelayanan yang diberikan kepada nasabah, pelayanan dari teller sebuah bank merupakan bagian yang sangat berpengaruh teradap pelayanan keseluruhan, karena hampir sebagian besar nasabah perbankan yang mendatangi banking hall bertujuan untuk melakukan transaksi perbankan di counter teller.

Fenomena umum yang sering terjadi di sebuah bank adalah nasabah harus antri dan menunggu sebelum mendapatkan pelayanan. Dalam upaya mendapatkan pelayanan dari teller, nasabah sering menilai kualitas system operasi suatu bank berdasarkan lamanya waktu menunggu atau kecepatan teller dalam memberikan pelayanan kepada para nasabahnya.

Oleh karena itu "mendahulukan kepuasan nasabah" adalah itikad yang mengagumkan, sebaik apa sebuah perusahaan diajak berbisnis biasanya tergantung pada orang-orang yang dipekerjakannya. Pengetahuan dan keahlian karyawan sangat penting bagi kemampuan perusahaan untuk memenuhi harapan atau kepuasan nasabah. Nasabah adalah semua orang yang menuntut perusahaan jasa untuk memenuhi suatu standar kualitas tertentu dan karena itu akan memberikan pengaruh pada perusahaan, sedangkan untuk kepuasan nasabah yaitu dapat didefinisikan secara sederhana sebagai suatu keadaan dimana kebutuhan, keinginan dan harapan nasabah dapat terpenuhi melalui produk yang dikonsumsi atau yang disarankan (Nasution 2014:48).

Kualitas pelayanan merupakan suatu bentuk penilaian konsumen terhadap tingkat pelayanan yang diterima dengan tingkat layanan yang diharapkan. Kepuasan pelanggan dalam bidang jasa merupakan elemen penting dan menentukan dalam menumbuh kembangkan perusahaan agar tetap eksis dalam menghadapi persaingan. Dalam perbankan masalah kualitas pelayanan menjadi faktor penting dalam menentukan keberhasilan bisnis ini, bank syariah khususnya telah menjadi tempat untuk menghimpun dan menyalurkan dana bagi masyarakat yang mempunyai misi berlandaskan keadilan, kemanfaatan, kebersamaan yang sesuai dengan syariah (Soemitra, 2009:25). 
Hal tersebut juga terjadi pada Bank Syariah Mandiri Cabang Cikupa khususnya sebagai tempat penelitian ini, kualitas pelayanan merupakan hal penting yang perlu diperhatikan terutama dengan posisi sebagai front line staff adalah sumber daya manusia yang dimiliki bank sebagai ujung tombak perusahaan dan sangat berperan dalam melayani nasabah seperti teller, customer service dan security.

Bank Syariah Mandiri Cabang Cikupa sebagai salah satu lembaga kepercayaan masyarakat harus mampu memberikan pelayanan yang berkualitas untuk memberikan kepuasan nasabahnya. Pelayanan yang lebih tinggi akan menghasilkan kepuasan nasabah yang tinggi pula. Oleh karena itu, program penyempurnaan pelayanan pada umumnya akan meningkatkan profitabilitas, perbaikan pelayanan merupakan komitmen total dari petugas bank, karyawan harus bekerja selaku team work untuk memuaskan nasabah (Sentono, 2000:308).

Bank Syariah Mandiri merupakan salah satu bank yang secara berkala melakukan perbaikan terhadap kualitas pelayanan frontliner dengan tujuan agar dapat meningkatkan berbagai kualitas layanan, terutama, pada layanan teller, customer service dan security sehingga mampu untuk bersaing secara sehat dengan bank lainnya guna memperoleh laba. Bank Syariah Mandiri merupakan salah satu perusahaan jasa yang mengedepankan pelayanan kepada nasabah dalam setiap operasionalnya, seorang petugas frontliner dituntut untuk memberikan pelayanan yang prima terhadap nasabah, agar frontliner dapat memberikan pelayanan yang prima, baik itu bagian teller maupun customer service maka ia harus mengenali karakteristik nasabahnya dengan baik.

Upaya peningkatan kualitas pelayanan oleh Bank Syariah Mandiri Cabang Cikupa bersifat inovatif dan berorientasi pada kepuasan nasabah. Namun masih muncul pertanyaan apakah hal tersebut benar- benar sudah memberikan kepuasan bagi nasabah Bank Syariah Mandiri Cabang Cikupa. Maka dari itu Bank Syariah Mandiri Cabang Cikupa perlu mengidentifikasi apakah pelayanan yang selama ini diberikan sudah sesuai dengan harapan nasabah, hal ini sebagai bukti perhatian Bank Syariah Mandiri Cabang Cikupa terhadap kepuasan nasabahnya. Karena apabila harapan nasabah lebih besar dari pelayanan frontliner yang diterima, maka nasabah tidak puas, sebaliknya apabila harapan nasabah sama atau lebih kecil dari pelayanan frontliner yang diterima, nasabah akan merasa puas (Suprapto, 2005:15).

Hal inilah yang mendorong penulis untuk mengetahui lebih jauh lagi tentang kepuasan nasabah setelah menerima pelayanan dari Bank Syariah Mandiri Cabang Cikupa, dengan ini pula dapat diketahui bahwa dimensi pelayanan seperti apa yang dapat memberikan kepuasan bagi nasabah. Penelitian ini diharapkan dapat membantu meningkatkan kepuasan yang 
diberikan oleh Bank Syariah Mandiri Cabang Cikupa bagi nasabahnya dengan tetap berlandaskan pada prinsip syariah islam, serta Bank Syariah Mandiri Cabang Cikupa dapat meningkatkan pelayanan yang prima sehingga nasabah semakin loyal kepada Bank Syariah Mandiri Cabang Cikupa.

\section{Kualitas Pelayanan}

Pelayanan menurut bahasa adalah perbuatan, yaitu perbuatan untuk menyediakan segala yang diperlukan orang lain atau pelanggan. Dewasa ini dalam kegiatan pelayanan dikenal istilah pelayanan prima, yang artinya adalah kepedulian kepada pelanggan dengan memberikan layanan terbaik untuk memfasilitasi kemudahan pemenuhan kebutuhan dan mewujudkan kepuasannya, agar mereka selalu loyal kepada perusahaan (Barata, 2004).

Kenyataan ini bisa dilihat, bahwa ada beberapa hal yang dapat memberikan kepuasan pelanggan yaitu nilai total pelanggan yang terdiri dari nilai produk, nilai pelayanan, nilai personal, nilai image (citra), dan biaya total pelanggan yang terdiri dari biaya moneter, biaya waktu, biaya tenaga dan biaya pikiran (Kotler dkk, 2000:50). Suatu hal nyata terjadi pada perusahaan perbankan di Indonesia, dimana setiap nasabah akan menginginkan pelayanan yang sesuai dengan harapan. Perlakuan seorang teller yang buruk terhadap nasabah disaat melakukan interaksi transaksi jasa keuangan pada bank tertentu akan membuat imagebank tersebut turun dimata masyarakat.

Menurut Philip Kotler (2002), jasa atau layanan adalah setiap tindakan atau kegiatan yang dapat ditawarkan oleh suatu pihak kepada pihak lain, yang pada dasarnya tidak berwujud dan tidak mengakibatkan kepemilikan apapun. Produksi layanan bisa berkaitan dengan produk fisik atau sebaliknya. Salah satu cara untuk menempatkan sebuah jasa lebih unggul dari para pesaing adalah dengan memberikan layanan yang jauh lebih bermutudibandingkan para pesaingnya. Hal tersebut diperlukan karena layanan merupakan kunci dalam memenuhi kebutuhan pelanggan.

Konsep yang saat ini masih dikenal dan sering digunakan pada kualitas pelayanan adalah konsep SERVQUAL.SERVQUAL sendiri pertama kali dikemukakan oleh Parasuraman, Berry dan Zeithaml. Awalnya konsep ini memiliki 10 dimensi dan sekarang lebih disederhanakan lagi dengan menggunakan 5 dimensi yang meliputi (Tjiptono, 2007: 273).

1. Bukti fisik (tangible), merupakan fasilitas fisik dari jasa yang diketahui oleh nasabah secara langsung dengan indicator sebagai berikut: Penampilan, persiapan dan peralatan, kerapian tempat kerja dan lingkungan tempat kerja.

2. Empati (empathy), mencakup kemudahan dalam menjalin relasi, komunikasi yang baik dengan nasabah dan perhatian pribadi serta 
pemahaman bank atas kebutuhan individual para pelanggan dengan indikator sebagai berikut: tanggap permintaan dan keluhan nasabah, menawarkan bantuan dengan antusias, sikap perhatian dan proaktif, sikap empathy dan kominkatif.

3. Reliabilitas (reliability), yaitu kemampuan sebuah bank dalam memberikan pelayanan yang dijanjikan dengan segera, akurat dan memuaskan dengan indicator sebagai berikut: Fokus pada pelayanan nasabah, antusias, menyambut nasabah dengan berdiri, focus senyum dan sampaikan salam pada nasabah, tulus mengucapkan terima kasih dan salam penutup.

4. Daya tanggap (responsiveness), yakni keinginan para petugas bank untuk membantu para nasabah dan memberikan pelayanan dengan sebaik mungkin dengan indicator sebagai berikut: Aktif membantu kelancaran nasabah, proses permintaan nasabah dengan cepat, akurat, selalu melakukan verifikasi dan konfirmasi, selalu menawarkan produk dan jasa fasilitas terbaru dengan menggunakan brosur, mengerjakan transaksi nasabah dengan cepat dan teliti dan ramah dalam melayani nasabah.

5. Jaminan (assurance), meliputi pengetahuan dan kesopancsantunan serta kemampuan para petugas bank untuk menumbuhkan rasa percaya nasabah kepada suatu bank dengan indicator sebagai berikut: sikap tanggung jawab, bicara dengan jelas, sikap teliti.

Fenomena yang sering terjadi disebuah bank adalah nasabah harus antri dan menunggu sebelum mendapatkan pelayanan. Dalam upaya mendapatkan pelayanan dari teller, nasabah sering menilai kualitas system operasi bank tersebut berdasarkan lamanya waktu tunggu atau kecepatan teller dalam memberikan pelayanan kepada nasabahnya.

Dengan demikian dapat disimpulkan bahwa pelayanan adalah keadaan dari suatu produk atau jasa yang menunjukan kemampuan dalam bentuk aktifitas yang di berikan oleh suatu pihak yang berkomunikasi bersamaan dengan produksi tanpa menghasilkan kepemilikan atas apapun akan tetapi mampu memberikan nilai tambah dalam rangka memenuhi kebutuhan dan keinginan pelanggan.

\section{Pelayanan dalam Perspektif Islam}

Menurut Eksmawati (2014:29) Islam mengajarkan bila ingin memberikan hasil usaha baik berupa barang maupun pelayanan hendaknya memberikan yang berkualitas, jangan memberikan yang buruk atau yang tidak berkualitas kepada orang lain. Seperti dijelaskan dalam Al-Qur"an surat Al-Baqarah ayat 267: Artinya: Hai orang-orang yang beriman, nafkahkanlah (di jalan Allah) sebagian dari hasil usahamu yang baik-baik dan sebagian dari apa yang Kami keluarkan dari bumi untuk kamu. dan 
janganlah kamu memilih yang buruk-buruk lalu kamu menafkahkan daripadanya, Padahal kamu sendiri tidak mau mengambilnya melainkan dengan memincingkan mata terhadapnya. dan ketahuilah, bahwa Allah Maha Kaya lagi Maha Terpuji.

Dalam ekonomi konvensional, pilihan didasarkan atas selera pribadi masing-masing. Manusia boleh mempertimbangkan tuntunan agama, boleh juga mengabaikan. Sedangkan dalam ekonomi Islam, keputusan pilihan ini tidak dapat dilakukan semaunya saja, semua perilaku harus dipandu oleh Allah lewat Al-Qur"an dan Hadis. Dalam Islam dan konvensional juga tidak mengalami perbedaan yang signifikan, perbedaanya hanya terletak pada proses penggunaannya yang mana ketika pelaku bisnis memberikan pelayanan dalam bentuk fisik hendaknya tidak menonjolkan kemewahan. Dalam mewujudkan nilai- nilai ibadah dalam bekerja yang dilakukan oleh setiap insan diperlukan adab dan etika yang membingkainya, sehingga nilainilai luhur tersebut tidak hilang sia-sia. Sebagaimana firman Allah dalam surat Adz- Dzariyyat ayat 56: Artinya: Dan aku tidak menciptakan jin dan manusia melainkan supaya mereka mengabdi kepada-Ku.

Ayat diatas menjelaskan bahwa Allah menciptakan manusia, tidak lain agar kita beribadah kepada-Nya dan tidak menyekutukan-Nya dengan apapun. Dalam hal ini dapat dikatakan bahwa semua aktivitas hidup manusia merupakan aktivitas penghambaan kepada Allah. Begitu juga dalam aktivitas ekonomi yang dilakukan harus dalam rangka kepatuhan terhadap segala ketentuan Allah SWT (Suryani, 2014:56).

Diantara adab dan etika bekerja dalam Islam adalah:

1. Ihsan, yakni perbuatan seseorang untuk melakukan perbuatan yang ma"ruf dan menahan diri dari dosa. Dia mendermakan kebaikan kepada hamba Allah yang lainnya baik melalui hartanya, kehormatannya, ilmunya maupun raganya. Salah satu bentuk ihsan yang paling utama adalah berbuat baik kepada orang yang berbuat jelek kepada kita, baik dengan ucapan atau perbuatannya.

2. Itqan, secara bahasa berarti mengerjakan sesuatu dengan sempurna. Namun dalam beberapa hal, itqan juga sering diartikan melampaui target. Dalam marketing, itqan bisa diartikan dengan penjualan produk minimal mencapai targetnya atau bahkan melampaui targetnya. Itqan dalam bekerja adalah bagaimana pekerjaan yang dilakukan seseorang tuntas, selesai, rapi dan tidak menimbulkan permasalahan lainnya.

3. Taysir, dalam memberikan pelayanan orang muslim juga harus memperhatikan aspek mempermudah orang lain, dalam proses mencari rezeki orang tersebut.

4. Samahah, kata samahah sendiri secara bahasa memiliki arti longgar, toleransi, membuat orang lain senang. Sehingga seorang pebisnis yang 
baik, ia akan memudahkan dan menyenangkan orang lain ketika bertransaksi dengannya.

5. Ash-Shidiq (kejujuran), kejujuran merupakan merupakan perilaku etis yang sesuai dengan al-Qur"an dan as-Sunnah yang merupakan akhlak terpuji. Kejujuran pula yang membuat seorang pekerja dapat mengembangkan bisnisnya dengan lebih baik lagi (Rachman, 2015:51).

Dengan demikian kejujuran merupakan nilai moral yang mendasar untuk menggapai ridha Allah dalam praktek perbankan syariah.

\section{Kriteria Penilaian Pelayanan}

Yuli (2012:92) mengatakan kinerja teller dalam penelitian ini merupakan kriteria penilian yang dianggap penting dan efektif dibutuhkan bagi seorang teller yang meliputi Doing job quickly, Result job is precisel, Easy to walk to, Responsibility of job, dan Hard worker.

\section{Definisi Kepuasan Nasabah}

Kepuasan atau satisfaction dari bahasa latin "satis" (artinya cukup baik) dan "facto" (melakukan atau membuat) dengan demikian kepuasan dapat diartikan sebagai pemenuhan sesuatu atau sesuatu yang memadai.Sedangkan menurut kotler, kepuasan merupakan tingkat perasaan dimana seseorang menyatakan hasil perbandingan antara hasil kerja produk atau jasa yang diterima dengan apa yang diharapkan. Pengertian lain dari kepuasan adalah hasil dari penilaian konsumen bahwa produk atau pelayanan telah memberikan tingkat kepuasan dimana tingkat pemenuhan ini bisalebih atau kurang.

Howard dan Sherth mengungkapkan bahwa kepuasan nasabah adalah situasi kognitif pembeli berkenaan dengan kesepadanan atau tidak kesepadanan antara hasil yang di dapat dengan pengorbanan yang dilakukan.

Jadi kepuasan merupakan fungsi dari perbedaan antara kinerja yang dirasakan dan harapan, jika kinerja dibawah harapan nasabah, maka nasabah tidak akan merasa puas, apabila kinerja sesuai harapan maka nasabah akan merasa puas, dan apa bila kinerja melampaui harapan maka nasabah akan merasa sangat puas, senang dan bahagia menggunakan jasa pada bank tersebut. 
Gambar 2.2

Diagram Konsep Kepuasan Nasabah

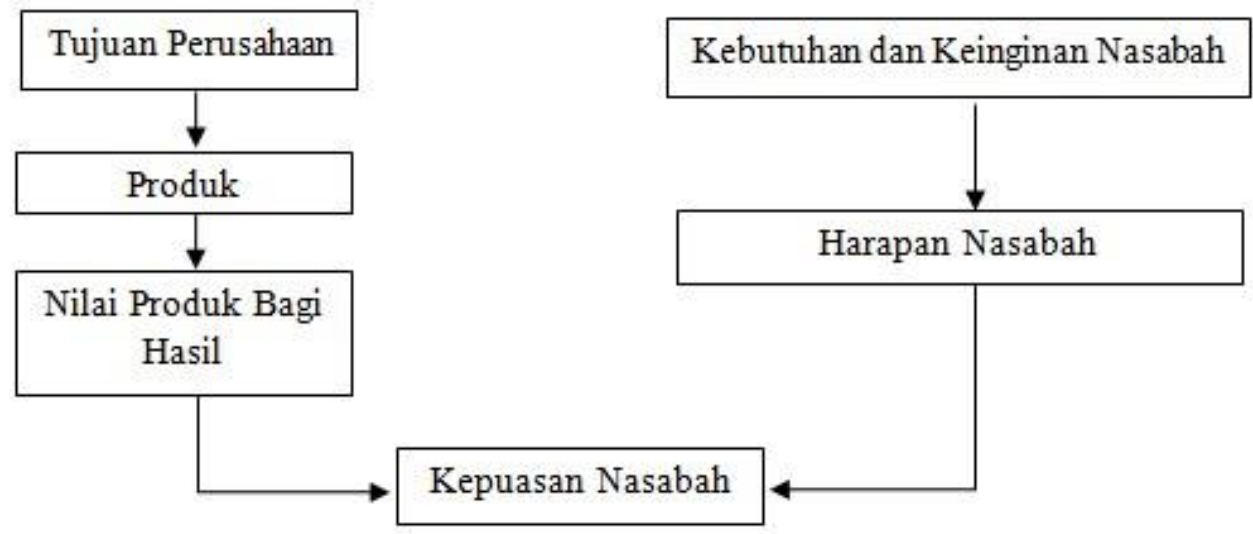

Sumber: Freddy Rangkuti, Measuring Customer Satisfaction, (Jakarta: GramediaPustaka Utama, 2003) hal.24

Kepuasan nasabah telah menjadi konsep sentral dalam teori dan praktik pemasaran, serta salah satu tujuan pokok bagi aktifis bisnis. Kepuasan nasabah berkonstribusi pada sejumlah aspek krusial, seperti terciptanya loyalitas pelanggan, meningkatkan reputasi perusahaan, berkurangnya elastisitas harga, berkurangnya biaya transaksi masa depan dan meningkatnya efisiensi dan produktifitas karyawan. Disamping itu fakta menarik bahwa pelanggan baru jauh lebih mahal dari pada mempertahankan pelanggan pada saat ini juga memicu meningkatkan perhatian pada kepuasan nasabah.

\section{Pengukuran Tingkat Kepuasan Nasabah}

Menurut kotler, ada 4 metode pengukuran kepuasan nasabah yaitu:

a. System keluhan dan saran. Metode ini untuk memantau kepuasan nasabah dengan cara memberikan kesempatan kepada nasabah untuk menyampaikan saran, pendapat, dan keluhan. Media yang digunakan dapat berupa kotak saran, kartu komentar dan saluran telepon bebas pulsa.

b. Survey kepuasan nasabah. Umumnya penelitian mengenai tingkat kepuasan nasabah banyak dilakukan melalui metode survey dengan mengajukan pertanyaan (kuisioner) kepada para nasabah. Melalui survey, perusahaan akan mendapatkan tanggapan dan umpan balik secara langsung dari pelanggan dan sekaligus juga memberikan tanda positif bahwa perusahaan menanti perhatian terhadap para nasabah.

c. Ghost shopping. Metode ini dilakukan dengan cara mempekerjakan orang untuk berpura-pura menjadi nasabah, kemudian nasabah 
bayaran tersebut menyampaikan temuan-temuannya mengenai kelemahan dan kekuatan dalam melayani nasabah. Selain itu juga, ia dapat mengamati atau menilai cara perusahaan menanggapi setiap keluhan.

d. Last cutomer analisis. Merupakan metode memantau kepuasan dengan cara menghubungi nasabah yang telah beralih ke perusahaan pesaing. Mereka dihubungi untuk memperoleh informasi tentang penyebab nasabah tersebut beralih ke perusahaan pesaing.

\section{Faktor-faktor Pendukung Kepuasan Nasabah}

Irawan (2002:02) mengemukakan bahwa terdapat lima komponen yang dapat mendorong kepuasan konsumen, yaitu:

a. Kualitas produk. Kualitas produk menyangkut lima elemen, yaitu performance, reliability, conformance, durability dan consistency. Konsumen akan merasa puas bila hasil evaluasi menunjukkan bahwa jasa yang mereka gunakan berkualitas.

b. Kualitas pelayanan. Pelanggan akan merasa puas apabila pelayanan yang baik yang sesuai dengan yang diharapkan. Dimensi kualitas pelayanan menurut konsep SerQual meliputi reliability, responsiveness, assurance, empathy dan tangible. Dalam banyak hal, kualitas pelayanan mempunyai daya diferensiasi yang lebih kuat dibandingkan dengan kualitas produk.

c. Faktor emosional. Kepuasan konsumen yang diperoleh pada saat menggunakan suatu produk yang berhubungan dengan gaya hidup. Kepuasan pelanggan didasari atas rasa bangga, rasa percaya diri, simbol sukses, dan sebagainya.

d. Harga. Komponen harga sangat penting karena dinilai mampu memberikan kepuasan yang relative besar. Harga yang murah akan memberikan kepuasan bagi pelanggan yang sensitif terhadap harga karena mereka akan mendapat value for money yang tinggi.

e. Kemudahan. Komponen ini berhubungan dengan biaya untuk memperoleh produk atau jasa. Pelanggan akan semakin puas apabila relatif mudah, nyaman dan efisien dalam mendapatkan produk atau pelayanan.

Dalam konteks perbankan, kepuasan nasabah merupakan suatu tujuan dalam dunia perbankan. Bank Syariah Mandiri KCP Cikupa melihat kepuasan nasabah itu dengan cara memberikan pelayanan dan produk disesuaikan dengan kebutuhan, serta memberikan kemudahan untuk memperoleh jasanya.

Kepuasan nasabah terkait dengan kualitas pelayanan internal dan kepuasan pelayanan internal karyawan tentu akan mendorong kepuasan karyawan. Kepuasan karyawan akan mendorong bangkitnya loyalitas 
karyawan pada perusahaan, selanjutnya loyalitas karyawan akan berdampak pada peningkatan produktivitas. Produktivitas karyawan akan menciptakan dan menentukan kepuasan nasabah. Akhirnya kepuasan nasabah ini akan menciptakan loyalitas nasabah. Faktor lainnya adalah rintangan pengalihan dan keluhan pelanggan.

Namun nasabah pun seringkali merasa tidak puas atas pelayanan yang diberikan oleh perusahaan. Sebab-sebab timbulnya ketidakpuasan pada nasabah:

a. Tidak sesuai antara manfaat atau hasil yang diharapkan dengan kenyataan atau apa yang didapat oleh konsumen.

b. Layanan selama proses menikmati jasa tidak memuaskan.

c. Perilaku personil atau karyawan perusahaan atau bank yang kurang memuaskan atau mengecewakan pelanggan.

d. Suasana dan kondisi fisik lingkungan tidak menunjang, misalkan lay out gedung yang tidak tertata rapi.

e. Biaya terlalu tinggi di atas bank lain atau tingkat bagi hasil yang terlalu membebankan nasabah.

f. Promosi iklan yang terlalu berlebihan, sehingga seringkali tidak sesuai dengan kenyataan.

Berdasarkan keterangan diatas, dapat disimpulkan bahwa sebabsebab timbulnya ketidak puasan nasabah pada umumnya dipengaruhi oleh beberapa faktor. Dalam konteks perbankan, Bank Syariah Mandiri KCP Cikupa berupaya untuk meningkatkan kinerja para pegawai agar sesuai dengan apa yang diharapkan nasabahnya serta memberikan pelayanan sesuai dengan kebutuhan dan keinginan nasabahnya.

Frontliner (Costumer service dan Teller) (Pratama,2015:142) mengatakan bahwa frontliner sebagai mana artinya secara harfiah adalah "garis depan", berarti merupakan petugas atau pegawai yang akan melakukan interaksi pertama ketika pelanggan mendatangi perusahaan. Ketentuan kerja frontliner telah diatur pada prosedur standar kerja. Standar tersebut meliputi penguasaan informasi tentang produk dan transaksi, kecepatan memproses transaksi, kerapian frontliner bank, kesopanan frontliner bank, dan keramahan frontliner.

Customer Service (Suryani, 2014:21). Dalam ilmu manajemen customer service dapat dikatakan sebagai ilmu dan dapat juga dikatakan sebaga seni. Dikatakan sebagai ilmu karena customer service termasuk dalam bagian pemasaran dan lebih dekat kepada penjualan dan customer service dapat dipelajari, diajarkan dan dipraktikan. Sedangkan customer service dikatakan sebagai seni di karenakan customer service sangat membutuhkan unsur kreativitas, inisiatif dan keterampilan dalam berhubungan atau berkomunikasi dengan orang lain. 
Jadi, customer service adalah ilmu dan seni tentang melayani pelanggan sebegai ujung tombak perusahaan yang berada di garis paling depan dan bertugas melayani pelanggan atau nasabah pada suatu perusahaan atau bank. (Afif, Faisal, dkk, 1996:26) (Suryani, 2014:21) Tugas dan fungsi bagian customer service adalah sebagai berikut:

a. Melayani nasabah dalam memberikan informasi kepada nasabah tentang produk-produk, jasa dan persyaratan-persyaratan yang terkandung dari setiap jenis produk bank.

b. Melaksanakan tahapan awal administrasi dalam pembukaan rekening

c. Memelihara hubungan yang baik dengan nasabah dalam pemberian informasi

d. Memberikan informasi produk-produk dan jasa kepada calon nasabah (Soeharto:62-63) (Suryani, 2014:21) dalam peraturan dasar yang harus dimiliki oleh customer service yaitu:

1) Berbusana rapih dan murah senyum

2) Memberikan ekspresi wajah terpercaya

3) Customer service sebagai perwakilan perusahaa, diharuskan untuk jaga sikap

4) Menyambut nasabah dengan sopan dan hangat

5) Selalu mendengarkan dengan baik apa yang dikatakan pelanggan

6) Memperlakukan nasabah dengan sopan dan hormat

7) Berbicara secara jelas, teratur dan baik

8) Meja kerja, counter dan ruangan harus rapih dan bersih

9) Menguasai pengetahuan tentang pekerjaan dan produk-produk bank dengan baik

Teller Afif, Faisal, dkk (1996:26) Suryani (2014:21) System teller adalah suatu rangkaian kerja pelayanan kepada nasabah di counter yang sebagian besar dari proses kerjanya diselesaikan sendiri oleh teller yang bersangkutan tanpa melalui prosedur kerja yang biasanya ditempuh dalam system kasir. Teller adalah karyawan bank yang bertanggung jawab terhadap lalu lintas uang tunai.

Teller disebut juga kuasa kas terbatas karena dalam jumlah uang terbatas karyawan bank tersebut dapat bertindak secara langsung untuk melakukan transaksi.

Dalam penerapan system teller terdapat beberapa jenis teller yaitu:

a. Corporate teller. Teller yang hanya melaksanakan pembayaran dan menerima setoran dari nasabah perusahaan.

b. Individual Teller. Teller ini hanya melaksanakan pembayaran kepada nasabah perorangan dan menerima setoran tunai dari perorangan.

c. Noncash Teller. Teller yang melaksanakan setoran non tunai.

d. Foreign Exchange Teller Teller yang melaksanakan pembayaran dan menerima setoran uang valuta asing. 
e. Local Currency teller. Teller yang melaksanakan pembayaran dan menerima setoran tunai dalam mata uang Negara tersebut.

Dalam system teller terdapat Jenis jabatan teller, yaitu:

1. Head Teller

2. Assisten Head Teller

3. Teller kliring

4. Teller

5. Teller khusus

6. Teller tabungan

7. Petugas stop payment

Dalam pelaksanaannya, system teller di tunjang oleh system manual dan system computer yang menyebabkan pekerjaan teller semakin cepat karena beberapa informasi dapat disajikan oleh computer, sehingga beberapa jenis pekerjaan dapat dilakukan dalam waktu singkat sebelum melaksanakan transaksi dengan nasabah. Berikut adalah tugas dan pekerjaan teller, yaitu:

a. Memeriksa identitas nasabah (petugas counter)

b. Meneliti keabsahan tanda tangan dan warkat (petugas specimen)

c. Mengesahkan tanda terima setoran dalam batas wewenangnya (pejabat kas)

d. Membayar dan menerima uang tunai (kasir)

e. Menerima setoran warkat bank sendiri dan warkat bank lain (petugas counter)

Dalam melaksanakan system teller terdapat etika dan peraturan teller, yaitu:

a. Penampilan. Sebaiknya teller menggunakan seragam sehingga ada kesan satu kesatuan dan merupakan ciri khas dari bank yang bersangkutan.

b. Kepribadian yang menarik. Sikap atau pembawaan yang ramah, dopan dan bersahabat terhadap nasabah merupakan keharusan bagi teller.

c. Pelayanan yang cepat dan tepat, menghindarkan nasabah menunggu terlalu lama.

d. Menjaga kerahasian bank dan kerahasian nasabah.

e. Teller tidak dibenarkan makan, membawa tas, menggantungkan baju dalam ruangan teller.

Alat kerja yang dapat menunjang tugas atau pekerjaan teller, tanpa mengabaikan faktor keamanan adalah sebagai berikut:

a. Sinar ultraviolet, yaitu alat pemeriksa keabsahan dokumen dan surat berharga lainnya.

b. Mesin penghitung uang kertas atau uang logam.

c. Mesin hitung, kalkulator, tellstrook machine 
d. Cash box, teller's box, box teller. Merupakan box yang terkunci khusus digunakan untuk menyimpan uang tunai, biasanya disimpan diruangan counter saat teller bekerja yang sepenuhnya merupakan tanggung jawab teller.

e. Speciment atau kartu contoh tanda tangan. Digunakan untuk melakukan pencocokan (verifikasi) tanda tangan yang terdapat pada house check yang disodorkan pada nasabah.

f. Validating machine. Digunakan untuk melegalisir setiap transaksi yang masuk melalui counter sesuai dengan kode teller masing-masing. Voucher atau bukti yang tidak dilegalisir dengan alat ini dianggap tidak sah.

g. Card dex Filling equipment untuk menyimpan stppayment order (penarikan atas nama rekening yang tidak dapat dibayar secara keseluruhan) atau daftar warkat-warkat yang dibatalkan oleh nasabah atau di nyatakan hilang.

h. Daftar uang palsu. Untuk memonitor penerimaan setoran tunai dari nasabah dan menghindari penerimaan uang palsu.

i. Daftar kurs harian. Daftar kurs ini digunakan untuk transaksi dalam valuta asing pada hari ini di keluarkan oleh pejabat yang berkecimpung dalam transaksi valuta asing.

j. $\quad$ Formulir-formulir kerja

1) Buku pencatatan pengambilan cash box dari khasanah (vault utama)

2) Buku persediaan kas di dalam khasanah (cash vault register)

3) Teller exchange (bon permintaan antar teller)

4) Daftar mutasi kas

5) Daftar posisi kas (rekapitulasi kas bank)

6) Daftar penerimaan/pengeluaran kas teller

Hasil penelitian yang diperoleh dari penelitian ini adalah sebagai berikut. Hasil penelitian menunjukkan bahwa variabel pengaruh kualitas pelayanan frontliner memiliki pengaruh positif dan signifikan terhadap kepuasan nasabah. Hal ini dibuktikan bahwa variabel pengaruh kualitas pelayanan frontliner dengan nilai Thitung $>$ Ttabel dengan tingkat signifikan 0,005. Dengan hasil tersebut dapat dikatakan bahwa faktor kualitas pelayanan frontliner mempunyai pengaruh terhadap kepuasan nasabah.

Berdasarkan analisis koefisien regresi sebesar 0,235 dengan tingkat signifikan 0,05 pengaruh kualitas pelayanan frontlinermemberikan pengaruh terhadap kepuasan nasabah. Dalam penelitian ini hasil analisis regresi sederhana yang terdapat dalam tabel diketahui bahwa koefisien determinasi yang dinotasikan $\mathrm{R}$ square adalah 0,225 atau 22,5\%. Hal ini menerangkan bahwa tingkat pengaruh kualitas pelayanan 
frontlinerberpengaruh terhadap kepuasan nasabah sebesar 22,5\%. Sedangkan sisanya di pengaruhi oleh variabel lain yang tidak di teliti oleh penulis.

Penelitian ini sejalan dengan penelitian yang dilakukan oleh Iis Suryani (2014) yang menguji pengaruh kualitas pelayanan frontliner terhadap kepuasan nasabah. Hasil penelitiannya menunjukkan bahwa persamaan $\mathrm{Y}=10,061+0,235 \mathrm{X}$ artinya, terdapat hubungan positiif antara pengaruh kualitas pelayanan frontliner terhadap kepuasan nasabah.

\section{Kesimpulan}

Setelah penulis melakukan penelitian terhadap Kualitas Pelayanan Nasabah, maka penulis mengambil kesimpulan sebagai berikut:

1. Berdasarkan hasil uji validitas yang melibatkan 30 Nasabah Bank Syariah Mandiri Cabang Cikupa yang dijadikan sebagai responden dan 60 butir pertanyaan setelah di analisis didapatkan hasil 50 butir pertanyaan yang valid dan 10 butir pertanyaan yang tidak valid dari indicator reliability, empathy dan kepuasan nasabah.

2. Berdasarkan hasil uji reliabilitas diketahui dari nilai Cronbach Alpha maka dapat disimpulkan bahwasannya antara variable tingkat kepuasan nasabah dengan pelayanan frontliner rata-rata diatas 0,60, maka disimpulkan bahwa instrument penelitian ini dinyatakan reliable menunjukan bahwa variabel $\mathrm{X}$ (pengaruh kualitas pelayanan frontliner) mempunyai hubungan yang baik.

3. Berdasarkan hasil Uji $\mathrm{T}$ pada tabel 4.24 menunjukan bahwa nilai Thitung untuk konstanta adalah 0,904 sedangkan Ttabel bias didapat pada tabel t-test, dengan $\mathrm{a}=0,05 . \mathrm{Df}=30$ (nilai $\mathrm{n}-2$, dimana $\mathrm{n}$ adalah jumlah data, 30-2 =28). Didapat $\mathrm{T}$ tabel adalah 1,701. Karena Thitung lebih besar dari Ttabel maka Ho ditolakdan Ha diterima, yang berarti adanya pengaruh kualitas pelayanan frontliner terhadap kepuasan nasabah. Berdasarkan probilitas jika probilitas $>0,05$ maka $\mathrm{H} 0$ diterima dan jika probilitas $<0,05$ maka Ho ditolak. Dari hasil uji diatas dapat disimpulkan bahwa semakin besar pengaruh pada Kualitas Pelayanan Frontliner maka semakin besar pula persentase Kepuasan Nasabah pada Bank Syariah Mandiri Cabang Cikupa.

4. Pada Uji F menunujukan bahwa nilai signifikansinya sebesar 0,005 dimana variable independen (Kualitas Pelayanan Frontliner) secara bersama berpengaruh signifikan terhadap variable dependen (Kepuasan Nasabah).

5. Berdasarkan hasil analisis koefisien korelasi maka dapat disimpulkan bahwasannya antara variable tingkat kepuasan nasabah dengan pengaruh kualitas pelayanan frontliner mempunyai hubungan yang positif. 